\title{
Gypsum-carbonate speleothems from Cueva de las Espadas (Naica mine, Mexico): mineralogy and palaeohydrogeological implications
}

\author{
Fernando Gázquez ${ }^{1}$, José-María Calaforra ${ }^{1 *}$, Paolo Forti ${ }^{2}$, Fernando Rull ${ }^{3,4}$, and \\ Jesús Martínez-Frías ${ }^{3,4}$
}

\begin{abstract}
:
Gázquez F., Calaforra J., Forti P., Rull F. and Martínez-Frías J. 2012. Gypsum-carbonate speleothems from Cueva de las Espadas (Naica mine, Mexico): mineralogy and palaeohydrogeological implications. International Journal of Speleology, 41(2), 211-220. Tampa, FL (USA). ISSN 0392-6672. http://dx.doi.org/10.5038/1827-806X.41.2.8

Some of the most outstanding hypogenic gypsum speleothems worldwide have been recently discovered in the Naica mines. The Cueva de las Espadas (Swords Cave), which lies at 120 m depth, hosts a rare type of speleothem called "espada" ("sword"). This study contributes to the understanding of the mineralogical composition of these singular speleothems, by means of their examination using micro-Raman spectroscopy, FT-IR spectroscopy and EDX microprobe. Our data revealed a complex mineralogy comprising a high-purity selenite core covered by several layers of calcite, aragonite and gypsum. Solid inclusions of polymetallic oxides (Mn-Pb-Zn) and graphite were also detected. The position of the water table during the genesis of the "espada" speleothems (over the past $60 \mathrm{kyr}$ ) was deduced from their mineralogy. Water level fluctuations at around $-120 \mathrm{~m}$ depth led to environmental changes within the Cueva de las Espadas. The selenite core and gypsum layers were precipitated under biphasic (water-rock) conditions when the cave was submerged under hydrothermal water. The aragonite precipitation required triphasic (air-water-rock) conditions and occurred when the water table intercepted the cave, allowing the $\mathrm{CO}_{2}$ exchange necessary for carbonate precipitation. Solid inclusions were trapped in an aerobic environment when the gypsum-aragonite boundary condition occurred. A thin calcite layer was precipitated under vadose conditions after the water table definitively moved out of the cave.
\end{abstract}

Keywords: gypsum speleothems; hydrothermal aquifer; water table oscillation; Naica caves

Received 20 January 2012; Revised 1 March 2012; Accepted 20 March 2012

\section{INTRODUCTION}

Of the over 350 cave minerals described in cave environments, the most abundant are calcite, aragonite and gypsum (Hill \& Forti, 1997; Onac \& Forti, 2011a,b). Nevertheless, few studies have described speleothems composed of alternating layers of at least two different minerals (Railsback et al., 1994; Ortega et al., 2005; Gázquez et al., 2012) whose succession

${ }^{1}$ Water Resources and Environmental Geology Research Group - Dept. of Hydrogeology and Analytical Chemistry - University of Almería, Crta.Sacramento s/n, 04120 La Cañada de San Urbano, Almería (f.gazquez@ual.es) (*jmcalaforra@ual.es)

${ }^{2}$ Italian Institute of Speleology - Dept. of Earth and GeologicalEnvironmental Sciences, Via Zamboni 67, 40126 Bologna, Italia (paolo.forti@unibo.it)

${ }^{3}$ Unidad Asociada UVA-CSIC al Centro de Astrobiología, University of Valladolid. Parque tecnológico Boecillo, 47151. Valladolid Spain (rull@fmc.uva.es)

${ }^{4}$ Centro de Astrobiología (CSIC-INTA). Crta. Ajalvir, 28850. Torrejón de Ardoz, Madrid, Spain (martinezfj@inta.es) has been often attributed to changes in environmental conditions within the caves.

In particular, the appearance of gypsum and carbonates in the same speleothem is infrequent and has been reported in previous studies only as a rare occurrence (Maltsev, 1997). This is a direct consequence of the fact that gypsum precipitation requires very specific conditions, quite unlike those for precipitation of carbonate. This specificity means that gypsum speleothems can be used as indicators of unusual palaeoenvironmental conditions in caves (Forti, 1996; Calaforra et al., 2008).

Some of the most outstanding gypsum speleothems worldwide have been recently discovered in the caves of the Naica mine (Chihuahua, Mexico), especially in the Cueva de los Cristales (Crystals Cave) (Forti, 2010). In addition, other caves have been also discovered at the Naica mine over recent decades, including the Ojo de la Reina (Queen's Eyes Cave) (Forti, 2010; Badino et al., 2011) and the Cueva de las Velas (Sails Cave) (Bernabei et al., 2007), both at 290 $\mathrm{m}$ depth. The more recently discovered Cueva de los Palacios (Palace Cave) (Beverly \& Forti, 2010) lies at a depth of $90 \mathrm{~m}$. 
Over the past decade, the Cueva de los Cristales has become the most well-known of these caves, due to its spectacularly large gypsum crystals, up to 11 meters long (London, 2003; García-Ruíz et al., 2007; Forti, 2010) (Fig. 1). The size of these speleothems exceeds any natural gypsum crystal previously found (Foshag, 1927; Rickwood, 1981; Garcia-Guinea et al., 2002) and their origin has been widely studied in previous works (Garcia-Ruiz et al., 2007; Forti, 2010; Garofalo et al., 2010).

In addition, other speleothems in the Cueva de las Espadas (at $-120 \mathrm{~m}$ level) provide additional value, which has led to their mineral composition being studied in great detail: in the deepest part of the cave, the selenite crystals are covered by mineral concretions that are not found on crystals higher up in the cave. The sequence of minerals coating the selenite crystals testifies to a succession of dramatically different conditions inside the Cueva de las Espadas.

In the present article, the complex mineralogy of the "espada" speleothems has been studied using micro-Raman spectroscopy, FT-IR spectroscopy (infrared spectroscopy with Fourier transformation) and EDX (Energy-Dispersive X-ray spectroscopy).

Although speleothem mineralogy has been traditionally studied using XRD (X-Ray Diffraction) (Ayalon et al., 1999; Finch et al., 2001; Cruz et al., 2005), few recently-published papers report the use of alternative techniques, such as Raman spectroscopy (White, 2006; Martinez-Arkarazo et al., 2007) and IR (infrared) spectroscopy (Martínez-Arkarazo et al., 2007). The present work represents a singular example where spectroscopic techniques have made possible the detection of mineral layers thinner than $1 \mathrm{~mm}$.

As a result, the mineralogical and geochemical data obtained from the "espada" speleothems allowed water table oscillations over the past $60 \mathrm{kyr}$ in the $\mathrm{Na}$ ica aquifer to be inferred, based on the environmental significance of the minerals deposited in the Cueva de las Espadas.

\section{GEOLOGICAL SETTING}

The Naica mining district lies in the central southern part of Chihuahua State in northern Mexico (Fig. 1 ). The Naica mine is a source of zinc and lead sulfides enriched in silver. The entrance to the mine lies at $1385 \mathrm{~m}$ a.s.1. on the southern face of the Sierra de Naica, an anticline structure consisting of carbonate rocks of Albian-Cenomanian age, which extends northeast to southwest (Franco-Rubio, 1978).

Intrusive magmatic activity during the Tertiary is responsible for the mineralization. This part of the North American subcontinent was originally thought to be characterized by acidic dykes some 26.2-25.9 Myr old occurring within the carbonate sequences (Megaw et al., 1988), although recently other authors date the dykes to 30.2 Myr BP (Alva-Valdivia et al., 2003). In the case of the Sierra de la Naica, the intrusions penetrate an old northwest-southeast fracture. The characteristics of the Naica groundwater are intimately linked with this dyke system, determining both its temperature, (currently around $53{ }^{\circ} \mathrm{C}$ at the mine level; Forti, 2010) and its hydrochemistry.

Contact between the groundwater and these igneous bodies has created a system of thermal saline flows with a large capacity for transporting heavy metals (Marin-Herrera et al., 2006). The brines are rich in $\mathrm{Si}, \mathrm{Cl}, \mathrm{Al}, \mathrm{Mn}, \mathrm{Fe}, \mathrm{Pb}, \mathrm{Zn}, \mathrm{Ag}, \mathrm{F}$ and $\mathrm{S}$; they flow along structural fissures, following the direction of the dykes, and interact with the limestone and felsic materials to create new minerals. The mineral paragenesis comprises pyrite, pyrrhotite, sphalerite, galena and chalcopyrite, all of which are formed from the hypersaline brines at high temperatures, in accordance with published data on fluid inclusions (Erwood, et al. 1979).

The Cueva de las Espadas was discovered in 1910 at a depth of $120 \mathrm{~m}$. It is $80 \mathrm{~m}$ long and its vertical development is $15 \mathrm{~m}$. The cave entrance is bounded by a subvertical fracture connected to the Montaña Fault and, at the time of the discovery, the cave mouth was completely covered by selenite gypsum crystals (Foshag, 1927; Rickwood, 1981). Nowadays, flow in the Cueva de las Espadas is very limited, being restricted to the condensation water on the cave walls and speleothems.

\section{MATERIALS AND METHODS}

\section{Sample description and sampling methodology}

The sample analyzed was a fragment of an espada (sword) speleothem that was already broken, which was collected from the floor of the Cueva de las Espadas. The sample consisted in the tip of a spar selenite crystal, about $10 \mathrm{~cm}$ across, covered with several 1 $\mathrm{cm}$ - thick layers of carbonate (aragonite and calcite) and gypsum. The espadas speleothems appear covering the floor and the walls of the cave, some of them $2 \mathrm{~m}$ long (Fig. 1).

The espada was cut longitudinally along its principal growth axis and parallel to the exfoliation plane of the selenite core at its centre (plane 001) (Fig. 3A). Raman spectroscopy analyses were performed on a polished section. An approximately $0.2 \mathrm{mg}$ powdered sample was extracted from each mineral layer using a Dremel tool with a $0.5 \mathrm{~mm}$ diameter drill bit for subsequent FT-IR analysis. A thin lamina was also prepared $(100 \mu \mathrm{m})$ for EDX analysis and observation by optical microscopy.

\section{Raman spectroscopy}

Raman spectroscopy analyses were performed at the UVA-CSIC-CAB (Associated Unit of the University of Valladolid - Astrobiology Centre, Valladolid, Spain). The excitation source was a Laser Research Electro-Optics (REO) working at $632.8 \mathrm{~nm}$. The KOSI HoloSpec f/ 1.8i spectrometer from Kaiser Optical covered a spectral range of $150-3800 \mathrm{~cm}^{-1}$ and a spectral resolution of $5 \mathrm{~cm}^{-1}$, whilst the CCD (charge-coupled device) employed was a DV420A-OE-130 model from Andor. The Raman head used was KOSI MKII, HFPH-FC-S-632.8 model from Kaiser Optical coupled by optical fibre to a Nikon Eclipse E600 microscope which, in turn, was attached to a JVC TK-C1381EG videocamera for visual analysis and precise control of the measured spots. An objective of 50X allowed microanalyses of up to $5 \mu \mathrm{m}$ diameter spots. Under these conditions, the laser power on the sample was maintained around $15 \mathrm{~mW}$ (corresponding irradiance of $2.4 \mathrm{KW} / \mathrm{cm}^{2}$ ), to ensure no thermal damage to the samples. Typical integration time for spectral acquisi- 

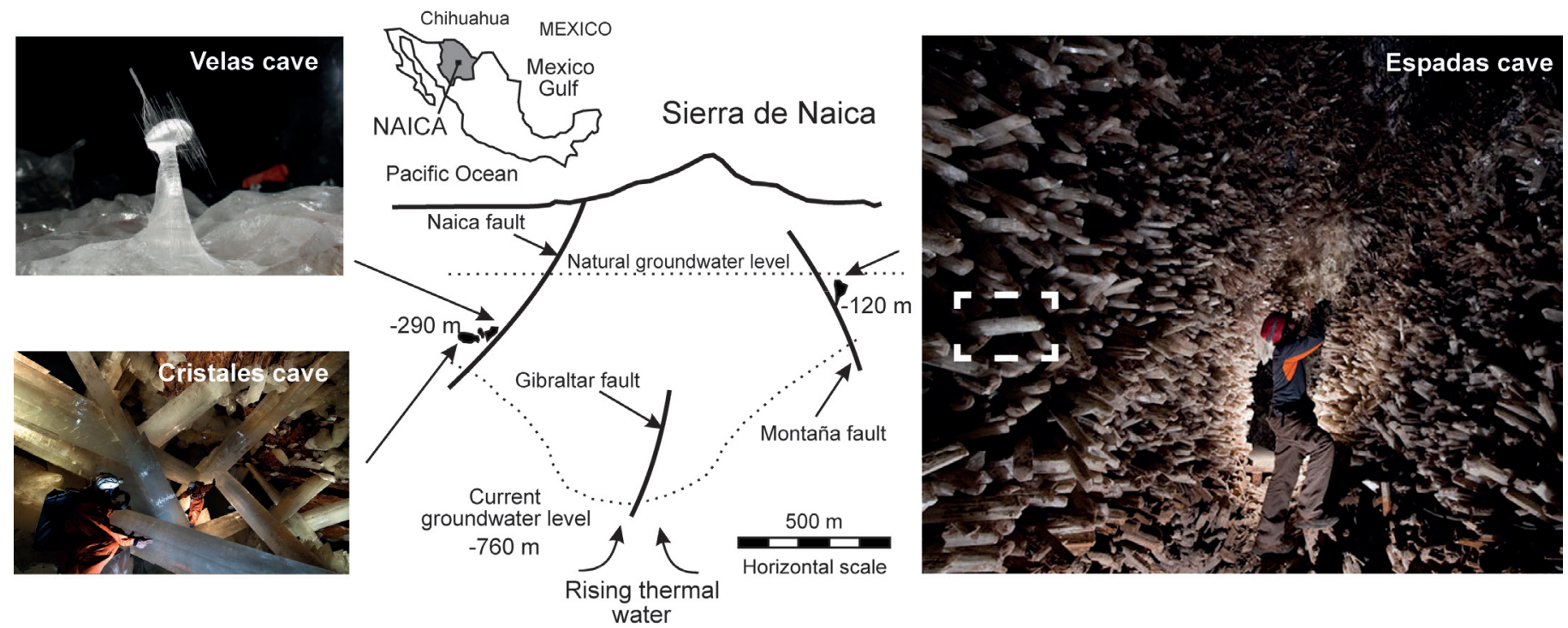

Fig. 1. Situation of the main caves in the Naica mine. The Cueva de las Espadas hosts the speleothems studied in this work. The rectangle on the photo marks an espada speleothem. Other caves studied in previous work are the Cueva de las Velas with peculiar speleothems formed through evaporation and capillarity (Berbabei et al. 2007) and the Cueva de los Cristales due to its spectacular huge gypsum crystals (Forti, 2010) (Photos by La Venta \& S/F Archives).

tion was 6 seconds and 5 accumulations were done. The sample was manually scanned, while the height of focus was varied in order to optimize the intensity of the spectra signals. Each mineral layer and some of the solid inclusions were analyzed by this technique. Spectra were compared to the gypsum, calcite and aragonite standards in the Raman mineralogical database RRUFF, (http://rruff.info/) and to our own spectral databases. The Raman vibration bands match those identified in previous work on gypsum (Berenblut et al., 1971), calcite (Rutt \& Nicola, 1974) and aragonite (Frech et al., 1980).

\section{FT-IR spectroscopy}

FT-IR analyses were performed at the UVA-CSIC$\mathrm{CAB}$ (Associated Unit of the University of Valladolid - Astrobiology Centre, Valladolid, Spain). Fouriertransform infrared spectra were recorded on a Perkin Elmer Spectrum 100 FTIR-ATR spectrometer in reflectance mode. Samples were scanned over the range 550-4000 $\mathrm{cm}^{-1}$, with 25 iterations. Spectral resolution was $0.4 \mathrm{~cm}^{-1}$, obtained from the $3028 \mathrm{~cm}^{-1}$ band in methane. The wavelength precision and the wavelength accuracy were $0.008 \mathrm{~cm}^{-1}$ and $0.02 \mathrm{~cm}^{-1}$, respectively at $2000 \mathrm{~cm}^{-1}$. Six samples were analyzed by this technique. The spectra obtained were compared to gypsum, calcite and aragonite standards on the mineralogical database RRUFF and to our own database. The IR bands overlap with those identified in previous work on gypsum (Takahashi et al., 1983), calcite (Gunasekaran et al., 2006) and aragonite (Frech et al., 1980).

\section{EDX (Energy-dispersive X-ray) mapping and micro- analyses}

EDX mapping and microanalyses were performed at the Astrobiology Centre (CSIC-INTA Madrid, Spain) and by the Technical Services Area of the University of Almeria (Spain), with the same instrument and under the same technical conditions. SEM (scanning electron microscopy) images, element mapping and mi- croanalyses were performed with a HITACHI S-3500 instrument in high vacuum mode coupled to an $\mathrm{Ox}$ ford INCA 7210 X-ray detector, using a current of 20 $\mathrm{kV}$. Semi-quantitative microanalyses were performed without metallization on a thin section of the sample. The diameter of the beam was approximately $1 \mu \mathrm{m}$. The limit of detection of this technique enables major elements like $\mathrm{Fe}, \mathrm{Mn}, \mathrm{Pb}, \mathrm{O}, \mathrm{Si}, \mathrm{Ca}, \mathrm{S}$ and $\mathrm{C}$ to be analyzed. Several element mappings were acquired.

\section{RESULTS}

Up to seven phases of mineral growth can be distinguished in the espada speleothem, as identified by EDX, micro-Raman spectroscopy and FT-IR spectroscopy (Figs. 2 and 3). The first of three gypsum phases was characterized by precipitation of euhedral selenite crystals $\left(G_{1}\right)$. The Raman spectrum of this gypsum exhibits the typical $\mathrm{SO}_{4}$ vibrations at $1009\left(\mathrm{u}_{1}\right), 414$ and $492 \mathrm{~cm}^{-1}\left(\mathrm{v}_{2}\right), 1142 \mathrm{~cm}^{-1}\left(\mathrm{u}_{3}\right), 621$ and $672 \mathrm{~cm}^{-1}\left(\mathrm{U}_{4}\right)$ (Berenblut et al., 1971). There were also vibrational bands from the structural water in the gypsum at 3407 and $3493 \mathrm{~cm}^{-1}$. Analysis by FT-IR also confirmed the gypsiferous nature of the espada's core, with IR signals at 1679, 1614, 1095, 665, 594 $\mathrm{cm}^{-1}$ and vibrations corresponding to water molecules at 3391 and $3498 \mathrm{~cm}^{-1}$. The EDX mapping revealed high concentrations of $\mathrm{S}$, confirming the mineralogical data.

The subsequent layer $\left(\mathrm{C}_{0}\right)$ was confirmed to be calcite from the Raman signals corresponding to vibration of $\mathrm{CO}_{3}$, at around $1752\left(2 \mathrm{v}_{2}\right), 1087\left(\mathrm{u}_{1}\right), 1437\left(\mathrm{u}_{3}\right)$ and $711\left(\mathrm{u}_{4}\right)$. FT-IR also confirmed the layer as calcite, with signals at 1390,867 and $719 \mathrm{~cm}^{-1}$. Other signals corresponding to gypsum also appeared (3519, $3392,1680,1619,1103,662$ and $\left.592 \mathrm{~cm}^{-1}\right)$, due to contamination of the sample from adjacent mineral layers during the manual sampling procedure.

The next layer in the succession was identified as aragonite $\left(A_{1}\right)$ by Raman spectroscopy, with signals at $1462\left(\mathrm{v}_{3}\right), 1087\left(\mathrm{v}_{1}\right)$ and $704\left(\mathrm{v}_{4}\right) \mathrm{cm}^{-1}$, and by FT-IR, with signals at $1440,1081,853$, and $711 \mathrm{~cm}^{-1}$. More- 


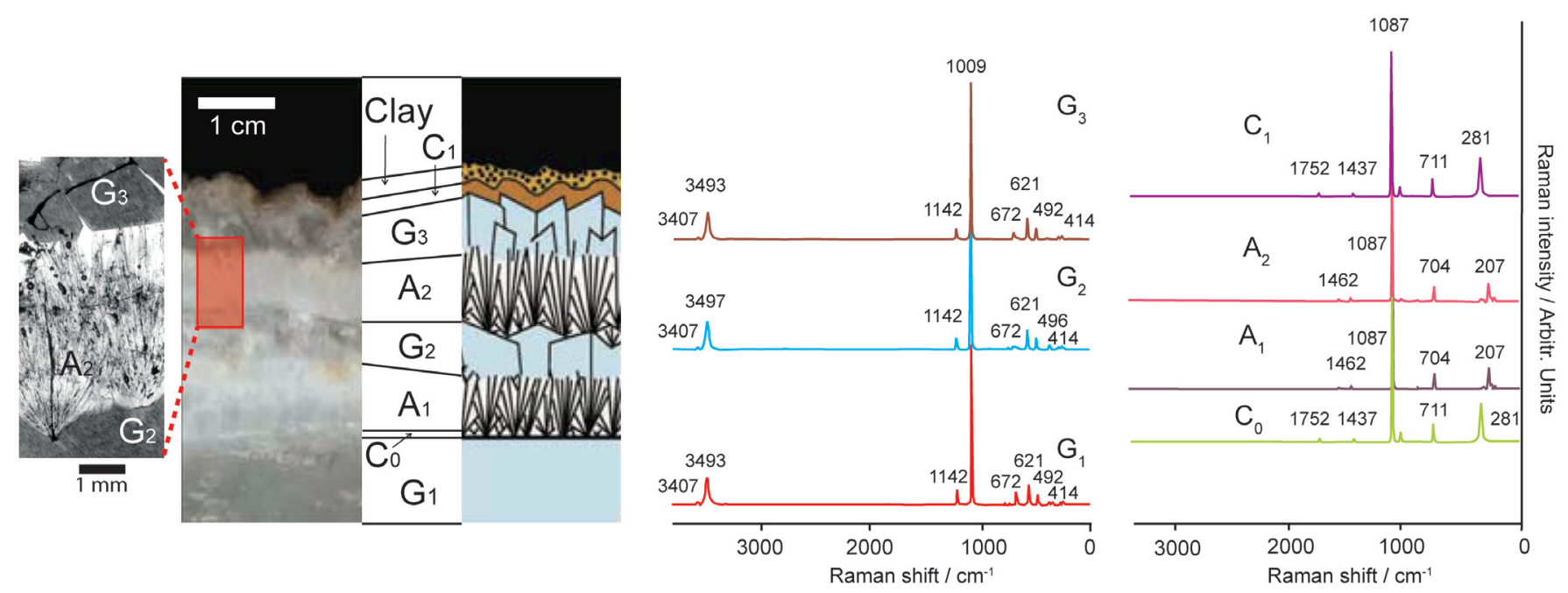

Fig. 2. Optical microscope image, stratigraphic sequence and microstratigraphy scheme of the concentric layers of an espada speleothem. Analysis using Raman spectroscopy confirmed alternating layers of gypsum $\left(G_{1}, G_{2}\right.$ and $\left.G_{3}\right)$, calcite $\left(C_{0}\right.$ and $\left.C_{1}\right)$ and aragonite $\left(A_{1}\right.$ and $\left.A_{2}\right)$.

A

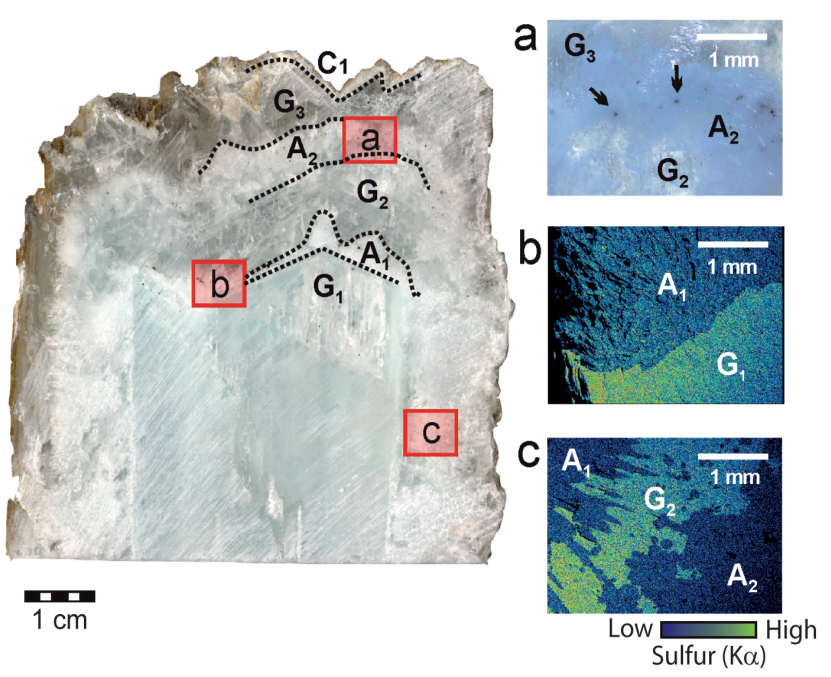

C

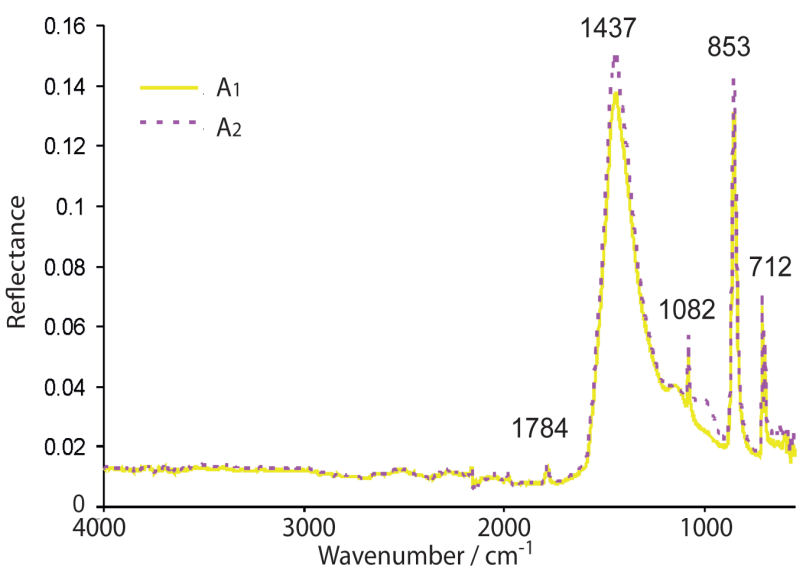

B

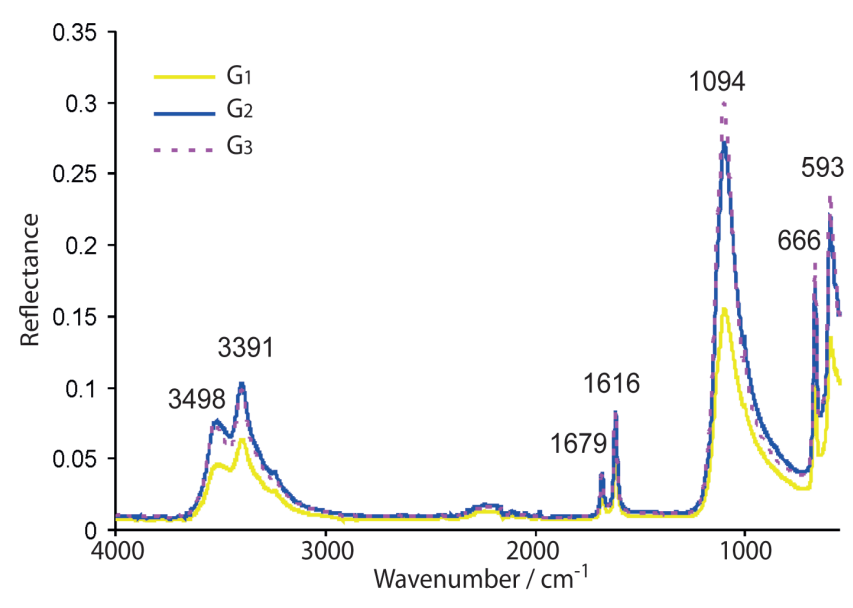

D

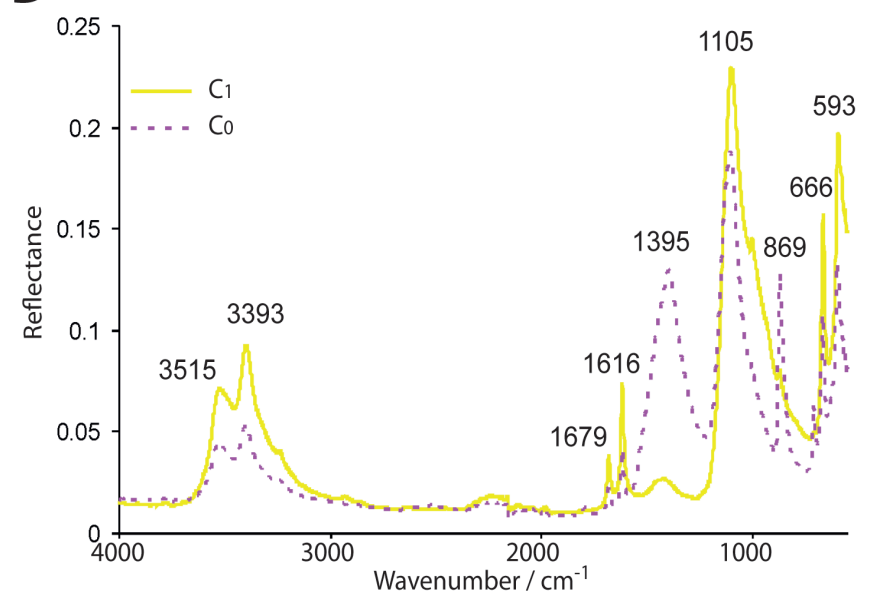

Fig. 3. A. Longitudinal section of the apical part of an espada speleothem. Detail of solid inclusions in the $A_{2}$ aragonite layer (a). EDX mapping of sulfur EDX allows the layers of gypsum and aragonite to be distinguished (b, c); $B$. IR spectrum of gypsiferous samples $\left(G_{1}, G_{2}\right.$ and $\left.G_{3}\right)$; C. IR spectrum of the aragonite layers $\left(A_{1}\right.$ and $\left.A_{2}\right)$; D. IR spectrum of the calcite layers $\left(C_{0}\right.$ and $\left.C_{1}\right)$. 

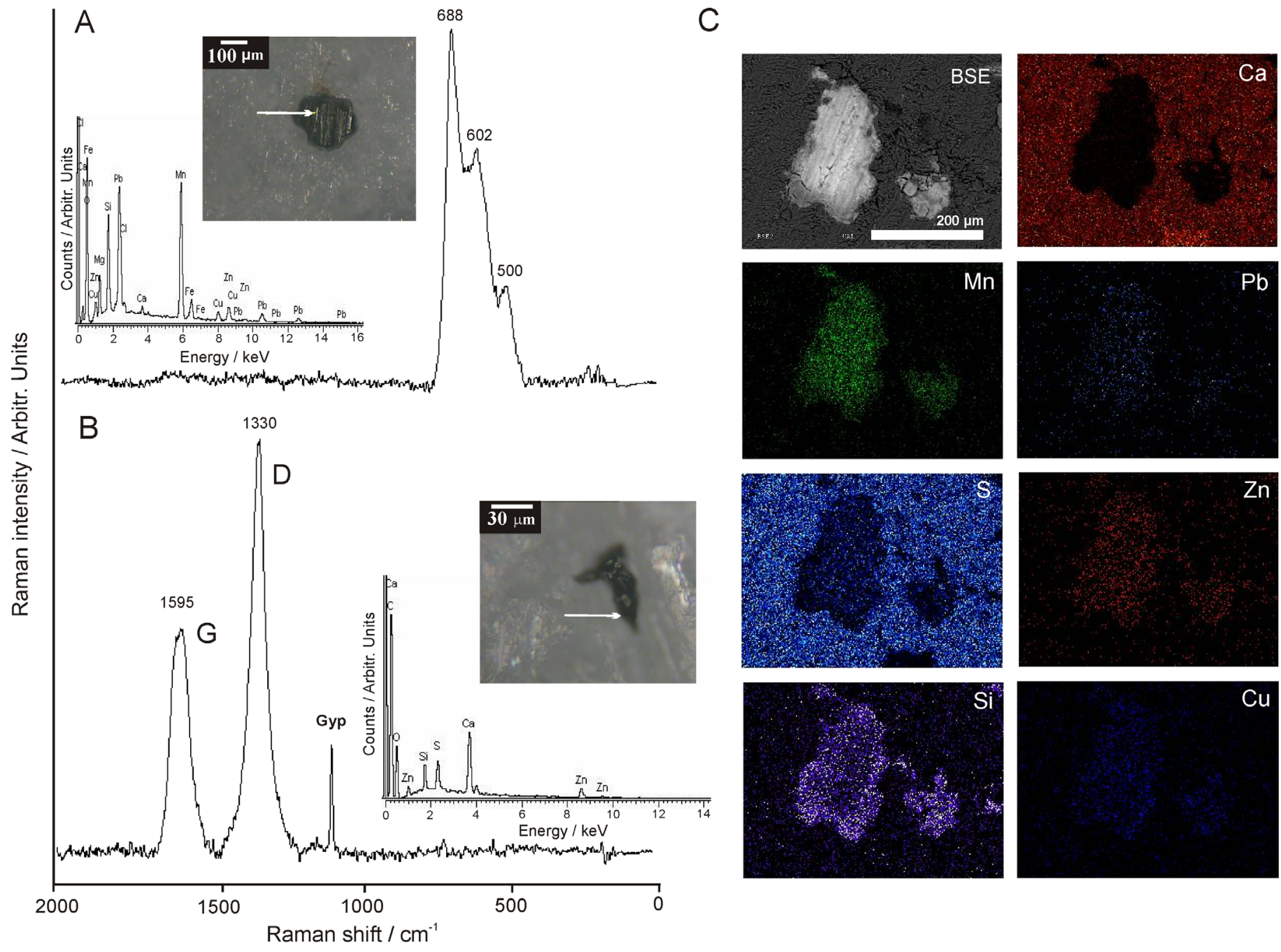

Fig. 4. A. Raman spectrum of a Mn-Pb-Zn oxide solid inclusion in an espada. The chemical composition was determined by EDX microanalysis; B. Raman spectrum of a solid graphite inclusion. EDX microanalysis revealed high concentrations of carbon and oxygen. G and $D$ are the main Raman bands of graphite (see main text); C. Back-scatter electron (BSE) photograph and EDX mapping of $\mathrm{Ca}, \mathrm{Mn}, \mathrm{Pb}, \mathrm{S}, \mathrm{Zn}, \mathrm{Si}$ and $\mathrm{Cu}$ of a solid inclusion. The heaviest elements $(\mathrm{Mn}, \mathrm{Pb}, \mathrm{Zn})$ appear lightest in color on the BSE images. In the mapping, the black zones indicate low concentration for each of the elements analyzed.

over, the concentration of $\mathrm{S}$ in this layer was very low as measured by EDX mapping. The next layer was identified as gypsum $\left(\mathrm{G}_{2}\right)$ using Raman spectroscopy. It exhibited the typical gypsum signals at $1009 \mathrm{~cm}^{-1}$ $\left(\mathrm{u}_{1}\right), 414$ and $492 \mathrm{~cm}^{-1}\left(\mathrm{v}_{2}\right), 1142 \mathrm{~cm}^{-1}\left(\mathrm{u}_{3}\right), 621$ and 672 $\mathrm{cm}^{-1}\left(\mathrm{v}_{4}\right), 3407$ and $3497 \mathrm{~cm}^{-1}$. Layer $\mathrm{A}_{2}$ was confirmed as aragonite, with similar Raman and FT-IR spectra to those of layer $A_{1}$. A further layer of gypsum $\left(G_{3}\right)$ followed, again with Raman and FT-IR signals similar to those of the selenite core $\left(G_{1}\right)$ and the gypsum layer $\mathrm{G}_{2}$. Lastly, a calcite layer $\left(\mathrm{C}_{1}\right)$ was identified by Raman spectroscopy (with vibrational signals at 1752, 1437, 1087, 711 and 281), as well as by FT-IR (typical calcite signal at $1395 \mathrm{~cm}^{-1}$ ), although this was masked by the presence of gypsum (Fig. 2 and 3 ).

In addition to the gypsum, calcite and aragonite, solid inclusions were found with two entirely different typologies. Of the five solid inclusions analyzed using micro-Raman, three revealed a similar Raman spectrum, with the main band at $688 \mathrm{~cm}^{-1}$ and two secondary bands at 601 and $504 \mathrm{~cm}^{-1}$. The first two sig- nals are assigned to $\mathrm{Mn}, \mathrm{Pb}$ and/or $\mathrm{Zn}$ oxides (Dunn et al., 2000; Mironova-Ulmane et al., 2009) although this Raman response could not be identified on the mineral database used; it cannot be ruled out that the third band is due to a $\mathrm{Si}-\mathrm{O}-\mathrm{Si}$ deformation mode.

The chemical composition of these inclusions includes high concentrations of oxygen (29\% wt)., Mn (25\% wt)., $\mathrm{Pb}(23 \% \mathrm{wt})$. and $\mathrm{Zn}$ (7\% wt).. Other minor elements also appear, such as $\mathrm{Si}(6 \% \mathrm{wt}) ., \mathrm{Mg}(4 \%$ wt)., $\mathrm{Cu}(3 \% \mathrm{wt})$., $\mathrm{Fe}(0.8 \% \mathrm{wt})$., $\mathrm{Ca}(0.7 \% \mathrm{wt})$. and $\mathrm{Cl}$ $(0.5 \% \mathrm{wt}) .$. These data reveal that we are dealing with oxides and hydroxides of $\mathrm{Mn}, \mathrm{Pb}$ and $\mathrm{Zn}$ with poorly defined crystalline structures.

In contrast, two of the analyzed inclusions were identified as amorphous carbon with a graphite-like structure, as revealed by the wide signals at around $1330 \mathrm{~cm}^{-1}$ (band D of graphite) and $1595 \mathrm{~cm}^{-1}$ (band $\mathrm{G}$ of graphite) (Reich \& Thomsen, 2004). The composition of these inclusions is mostly carbon (58\% wt). and oxygen $(26 \% \mathrm{wt})$. with traces of $\mathrm{Ca}, \mathrm{Si}, \mathrm{S}$ and $\mathrm{Zn}$. 


\section{Genesis of the giant selenite crystals}

The genesis of gypsum speleothems of the Cueva de las Espadas, like that of the other huge gypsum speleothems found in the Cueva de los Cristales (Forti, 2010) and in Ojo de la Reina Cave (Badino et al., 2011) is related to upward flow of thermal water in the system. Oxidation of metal sulphides enriched the groundwater in sulphates and led to precipitation of anhydrite at high temperature. Later, gradual cooling of the system caused dissolution of anhydrite (GarciaRuiz et al., 2007), slightly supersaturating the water in gypsum below $58^{\circ} \mathrm{C}$ (Hardie, 1967). Finally, under a cooler regime, this gypsum precipitated underwater as selenite crystals (Fig. 5A).

The incredible size of the selenite crystals in the Naica caves is attributable to the extremely low rates of nucleation and precipitation, which meant that the crystals grew very slowly (Forti \& Lo Mastro, 2008). This kind of precipitation is possible only under conditions where the degree of saturation is consistently close to equilibrium over a long period (Garcia-Ruiz et al., 2007). The genesis of the selenite cores $\left(G_{1}\right)$ in Cueva de las Espadas described in this study is similar to that of the huge selenite crystals in Cueva de los Cristales (García-Ruíz et al., 2007; Forti, 2010).

However, the difference in size between the selenite crystals in the Cueva de las Espadas and in the Cueva de los Cristales is based primarily on the characteristics of the water from which they were precipitated. Studies of fluid inclusions in the gypsum of both speleothems indicate that the salinity of the water from which the selenite cores of the espadas were precipitated (4-6 Eq. wt \% $\mathrm{NaCl}$ ), was greater than that which formed the large gypsum crystals in the Cueva de los Cristales (3 - 5 Eq. wt \% NaCl; Garofalo et al., 2010). This could imply a higher rate of nucleation and precipitation of gypsum in the Cueva de las Espadas, which would explain the greater density of selenite crystals and their smaller size compared to the Cueva de los Cristales. On the other hand, temperature does not appear to have played a fundamental role in the different sizes of gypsum crystals in these two caves, as indicated by the homogenization temperature calculated from the fluid inclusions (around $55{ }^{\circ} \mathrm{C}$ in both types of speleothem) (Garofalo et al., 2010).

Meanwhile, the length of time over which selenite precipitation took place in each cave must be a factor in the formation of these gigantic crystals. The formation time of the crystals in the Cueva de los Cristales has been estimated to be $245 \mathrm{kyr}$ for the largest crystals, based on the current rate of gypsum precipitation at $-590 \mathrm{~m}$ in the mine (Forti \& Lo Mastro, 2008; Sanna et al., 2011). The innermost part of one of the largest crystals dates to $169+101 /-52$ kyr BP (Sanna et al., 2010), whilst the outermost part dates back to 34.5 $\pm 0.8 \mathrm{kyr}$ BP (Sanna et al., 2010). In contrast, the selenite core of the espadas dates back to $57 \pm 2 \mathrm{kyr} \mathrm{BP}$ (Sanna et al. 2010), indicating that the period of crystal growth in the Cueva de los Cristales could have been much longer than the period of precipitation of the current selenite cores in the Cueva de las Espadas. The first gypsum growth stage of the espada speleothems $\left(G_{1}\right)$ indicates that this was below the water table at around 60 kyr BP.
Metallic oxides precipitation as solid inclusions

Polymetallic oxides and hydroxides are frequently encountered in caves, and among them manganese minerals are especially abundant (Hill \& Forti, 1997). Over recent years, the mineralogy, morphology and genesis of this kind of speleothem has been studied in a variety of caves (Onac, 1996; Onac et al., 1997; White et al., 2009; Gázquez et al., 2011). Manganese oxides usually occur in caves as black crusts on the walls and floors. Sometimes they form the base of speleothems, but they occasionally form part of stalactites, stalagmites or flowstones (Hill \& Forti, 1997). "Fossilized" layers of Fe and Mn oxides inside other speleothems have only been described in a few studies (Peck, 1986; Gázquez et al., 2011).

The speleothems of the Cueva de las Espadas underwent episodes during which polymetallic oxides and hydroxides were precipitated; these appear as solid inclusions which were mostly co-precipitated in the aragonite layers $\left(A_{1}\right.$ and $A_{2}$ ) (Fig. 5B). 60 $\%$ of the solid inclusions studied exhibited a high content of $\mathrm{Mn}, \mathrm{Pb}$ and $\mathrm{O}$, with lesser amounts of $\mathrm{Zn}$, $\mathrm{Cu}$, Si and Mg (Fig. 4A,C). Although the inclusions were analyzed using micro-Raman, the Raman signals obtained do not correspond to any of the polymetallic oxides of one or more of these elements in the RRUFF mineralogical database. This can be explained if the minerals in these inclusions do not have a sufficiently crystalline structure for them to be recognized. Nevertheless, signals were recorded that may be related to the presence of one or more polymetallic oxides.

The origin of the $\mathrm{Mn}, \mathrm{Pb}$ and $\mathrm{Zn}$ that gave rise to formation of the solid inclusions in the espadas is linked to mobilization of these metals, present as mineralizations within the host rock and in the ore minerals. The phreatic conditions, when the cave was submerged under water, led to mobilization of $\mathrm{Mn}, \mathrm{Pb}$ and $\mathrm{Zn}$, since these metals are soluble in their reduced state $\left(\mathrm{Mn}^{2+}, \mathrm{Pb}^{+2}\right.$ and $\left.\mathrm{Zn}^{2+}\right)$. Such a process is only possible in an anoxic medium (Calvert \& Pedersen, 1996). Precipitation of these elements as poorly crystalline oxides and hydroxides occurred when the water level fell and the phreatic surface intercepted the Cueva de las Espadas. The atmosphere generated in the cave permitted some aeration of the water and this allowed oxidation of these metals and their precipitation in the form of solid inclusions in the espadas. As well as the metallic inclusions, another type of inclusion was distinguished, accounting for $40 \%$ of the inclusions studied. The Raman signal and the chemical composition of these inclusions indicate that they are graphitic, probably derived from infiltration of surface water (Fig. 4B). This fact confirms the connection of the Naica aquifer to meteoric water sources, and suggests that the oscillations in phreatic level could have been related to climate changes.

\section{Aragonite - microcrystalline gypsum layers al- ternation}

In the Cueva de las Espadas, carbonate (aragonite and calcite) was deposited during certain stages, in addition to the gypsum. The aragonite layers 

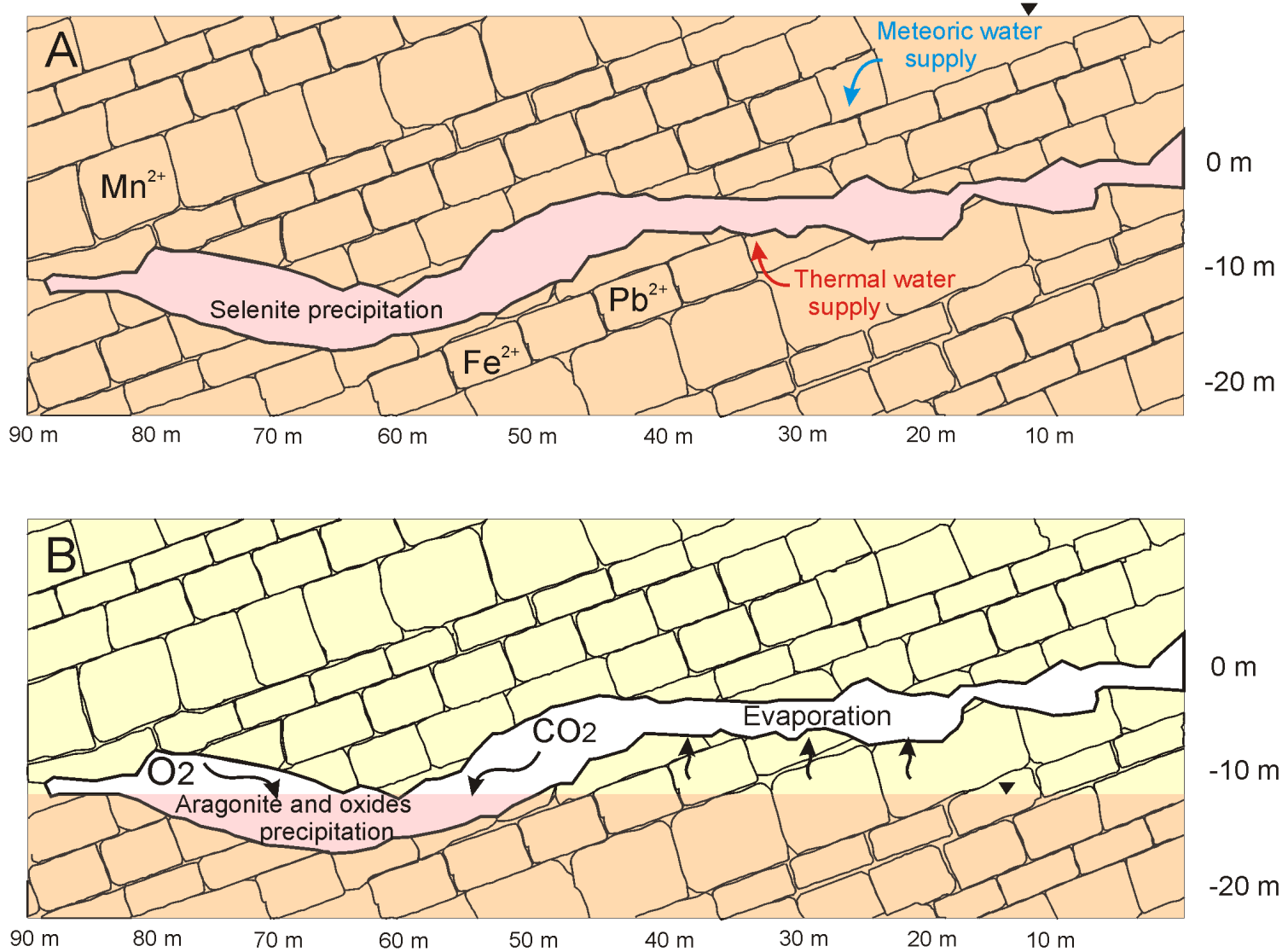

$0 \mathrm{~m}$

$-10 m$

$-20 m$
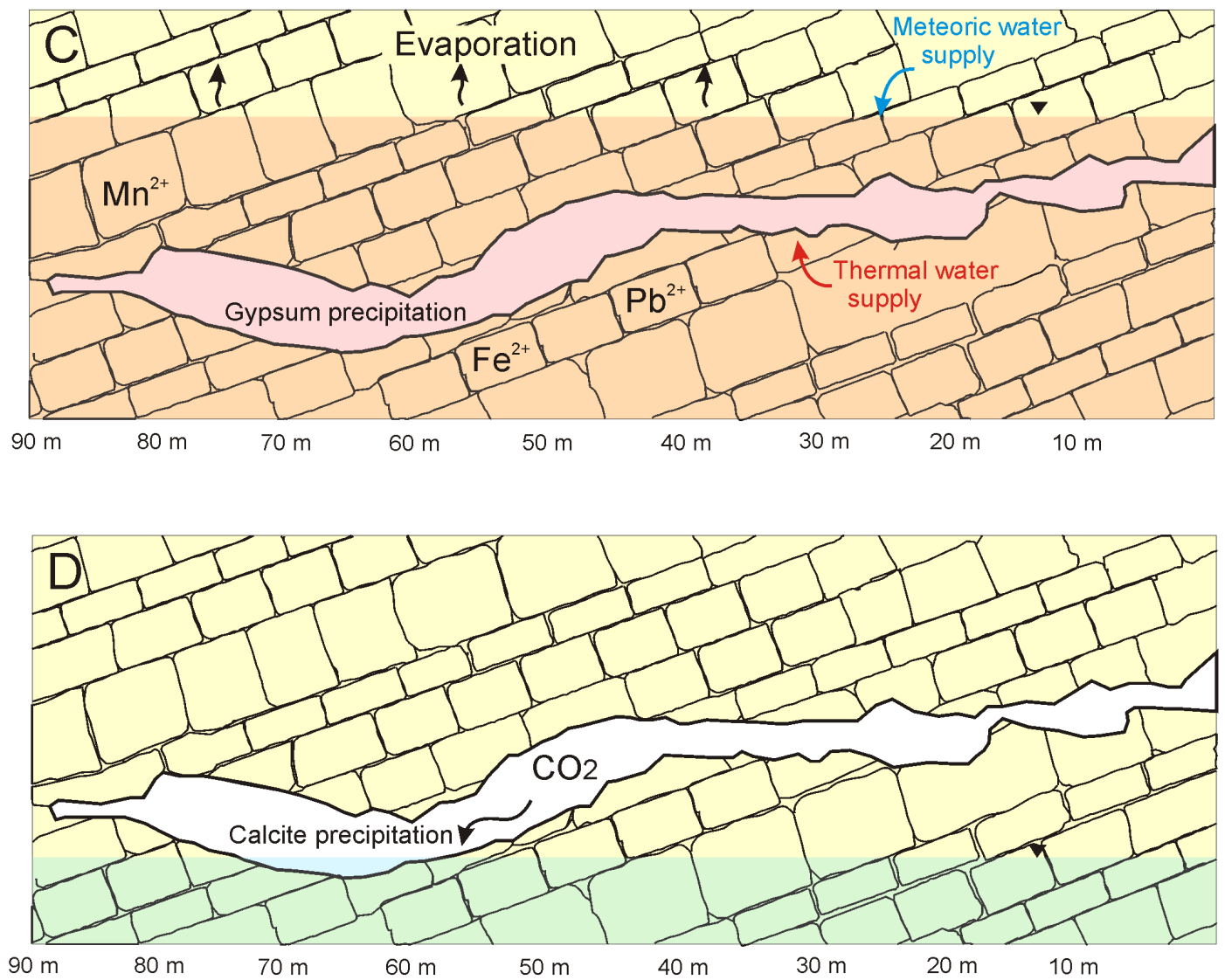

$0 \mathrm{~m}$

Fig. 5. Evolutionary diagram of the water table position in the Cueva de las Espadas. A. Precipitation of selenite cores $\left(G_{1}\right)$ under biphasic conditions ( $57 \pm 2 \mathrm{kyr} \mathrm{BP}$ ); B. Precipitation of $\mathrm{Zn}-\mathrm{Mn}$-Pb solid inclusions in an oxygenic environment and precipitation of the aragonite layers $\left(A_{1}\right.$ and $\left.A_{2}\right)$ under triphasic conditions $(14.5 \pm 2 \mathrm{kyr}$ and $7.9 \pm 0.1 \mathrm{kyr} B P)$; C. Precipitation of microcrystalline gypsum $\left(G_{2}\right.$ and $\left.G_{3}\right)$ under biphasic conditions and evaporation on the water table (14.5 $\pm 2 \mathrm{kyr}-7.9 \pm 0.1 \mathrm{kyr}$ and 7.9 $\pm 0.1 \mathrm{kyr} \mathrm{BP}-$ Late Holocene); D. Precipitation of calcite $\left(C_{1}\right)$ under triphasic conditions and falling temperature. Deposition of mining aerosols and cemented clays under atmosphere cave conditions (Late Holocene - recent period). 
$\left(A_{1}\right.$ and $\left.A_{2}\right)$ were precipitated under triphasic conditions (air-water-rock) when the water table fell (Fig. 5B). The bottom of Cueva de las Espadas became an underground lake with limited water input. Diffusion of $\mathrm{CO}_{2}$ from the cave atmosphere into the water, and the progressive fall in groundwater temperature led to precipitation of aragonite. The $\mathrm{CO}_{2}$ input into the Cueva de las Espadas lake should cause slight acidification of the water but this would have been controlled by the buffering effect of the dolomite host rock. Carbonate precipitation from diffusion of $\mathrm{CO}_{2}$ into a saturated gypsum-rich solution has also been reported in some gypsum caves (Forti, 2003). In addition, the widespread presence of organic matter and the graphite inclusions in the aragonite layers may suggest possible organic buffering reactions. ${ }^{230} \mathrm{Th} /{ }^{234} \mathrm{U}$ dating revealed that the first aragonite layer dates back to $14.5 \pm 2 \mathrm{kyr}$ BP (Sanna et al., 2010), which means that the water table at that time intercepted the Cueva de las Espadas, resulting in triphasic conditions during the Last Deglaciation period.

A subsequent rise in the water table led to biphasic conditions in the cave (water-rock) and gypsum started precipitating again, but under different circumstances (Fig. 5C). Before the new gypsum precipitation stage, evaporation at the water table surface (above $-120 \mathrm{~m}$ ) led the solution to be saturated in gypsum. This observation is supported by the high salinity of the fluid inclusions in the gypsum layer precipitated during this stage $\left(G_{2}\right)$, which are higher than those analyzed in the gypsum core $\left(G_{1}\right)$ (Garofalo et al., 2010).

At a later stage, the water table fell again leading to renewed triphasic conditions, with carbonate precipitation derived from $\mathrm{CO}_{2}$ diffusing from the cave atmosphere into the lake water. Under these circumstances, the precipitation of gypsum ceased and aragonite $\left(\mathrm{A}_{2}\right)$ began precipitating again. ${ }^{230} \mathrm{Th} /{ }^{234} \mathrm{U}$ dating revealed the age of this aragonite layer is $7.9 \pm 0.1 \mathrm{kyr}$ BP (Sanna et al., 2010). These facts point to triphasic conditions similar to those occurred $14.5 \pm 2$ kyr BP repeated in the Cueva de las Espadas during the Holocene.

Subsequently, the water table rose again and evaporation at the piezometric surface led to precipitation of a further gypsum layer $\left(\mathrm{G}_{3}\right)$. Finally, a thin calcite layer precipitated due to small meteoric water inputs in a cooler setting than in previous stages $\left(\mathrm{C}_{1}\right)$ when the main phreatic level had definitely left the cave dry (Fig. 5D). Most recently, when the cave was intercepted by mining operations, mining activity generated aerosols and particles in suspension that have been deposited over the espadas.

In addition to the layers described above, a further layer of calcite was detected. This calcite layer $\left(\mathrm{C}_{0}\right)$ was generated at the boundary between the selenite core $\left(G_{1}\right)$ and the first layer of aragonite $\left(A_{1}\right)$. Its origin appears to be related to the isomorphic conversion of aragonite to calcite. This hypothesis is strongly supported by the current presence of similar thin aragonite precipitates at $-590 \mathrm{~m}$ in the Naica mine, which are evolving towards calcite due to high temperature (Forti et al., 2008).

\section{CONCLUSIONS}

The espadas in the Cueva de las Espadas are a singular example of complex speleothems comprising gypsum and carbonates (aragonite and calcite) that may never be found again. Interest in these formations is not due simply to their uniqueness from a speleogenetic point of view, but also because of what they reveal about the dynamics and variability of the hydrogeochemistry of the Naica aquifer over the period of formation of these speleothems.

Based on this study we can conclude that there is a direct relationship between the palaeohydrogeology of the Naica aquifer and the mineralogy of the speleothems formed in Cueva de las Espadas. Water temperature in the aquifer and the biphasic-triphasic (water-rock and air-water-rock) environment determined that carbonate and gypsum were the minerals precipitated in the espadas speleothems. The alternation of the layers implies variability in the palaeohydrogeology of this aquifer (temperature and salinity of water and phreatic level fluctuations). The mere presence of selenitic gypsum indicates periods during which the cave lay completely below the water table. It is also relevant that there is a big difference in texture between the gypsum monocrystal at the centre of the speleothem and the outer gypsum layers. This difference in crystallization confirms, at the very least, changes in the environmental conditions during the crystallization phase caused by an increase in salinity induced by evaporation at the phreatic surface. Under very stable conditions, the selenite cores precipitated, and later, a variable environment generated the external gypsum layers. These observations show that the gypsiferous phases are related to periods when the watertable lay above the level of the Cueva de las Espadas, at $57 \pm 2 \mathrm{kyr} \mathrm{BP}$ and during some periods of the Holocene.

Meanwhile, the aragonite layers are indicators of periods when the phreatic level fell. Consequently, part of the cave was exposed to vadose conditions, which allowed gaseous exchange between the cave's atmosphere and the water in the subterranean lake of the Cueva de las Espadas. Aeration of the cave also allowed the precipitation of $\mathrm{Mn}, \mathrm{Pb}$ and $\mathrm{Zn}$ oxides in the form of solid inclusions. The ages of the aragonite layers suggest that the watertable intercepted the cave several times over the past $15 \mathrm{kyr}$. Lastly, the calcite layer is an indicator of a period during the Late Holocene when the water temperature in Cueva de las Espadas was even lower than during the development of the aragonite layers.

In conclusion, the espadas speleothems reflect the water table fluctuation of the Naica aquifer over the past $60 \mathrm{kyr}$.

\section{ACKNOWLEDGMENTS}

The authors are grateful for the support from the Servicios Centrales de Investigación (University of Almeria), where the SEM photographs and EDX microanalysis were done. We are especially grateful to the technician responsible for these instruments, Esmeralda Urea. We should also like to thank Aurelio Sanz, the technician who performed the micro-Raman analyses and to Maria Serrano who helped in the EDX mapping analyses. 
Financial support was made available through the "PALEOGYP" International Collaboration Project (CGL2006-01707/BTE Ministry of Science and Innovation, Spain), the Spanish Science grant AP2007-02799, the "GLOCHARID" Project of the Junta de Andalucia Regional Government and the funds of the Water Resources and Environmental Geology Research Group (University of Almeria). Field work and logistics were supported by the Peñoles Company and the "NAICA PROJECT" Speleoresearch \& Films of Mexico City in co-operation with La Venta Exploration Team (Italy). Photographs were kindly supplied by La Venta \& S/F Archives. Finally, the authors appreciate the suggestions from four reviewers (one of them Bogdan P. Onac), which helped to improve the original manuscript. Sarah Steines is also greatly acknowledged for improving our English.

\section{REFERENCES}

Alva-Valdivia L.M, Goguitchaichvili A. \& UrrutiaFucugauchi J., 2003 - Petromagnetic properties in the Naica mining district, Chihuahua, Mexico: Searching for source of mineralization. Earth Planets Space, 55: 19-31.

Ayalon A., Bar-Matthews M. \& Kaufman A., 1999 - Petrography, strontium, barium and uranium concentrations, and strontium and uranium isotope ratios in speleothems as palaeoclimatic proxies: Soreq Cave, Israel. The Holocene, 9: 715-722. http://dx.doi.org/10.1191/095968399673664163

Badino G., Calaforra J.M., Forti P., Garofalo P. \& Sanna L., 2011 - The present day genesis and evolution of cave minerals inside the Ojo de la Reina cave (Naica Mine, Mexico). International Journal of Speleology, 40(2): 125-131.

http://dx.doi.org/10.5038/1827-806X.40.2.5

Berenblut B.J., Dawson P. \& Wilkinson B.R., 1971 The Raman spectrum of gypsum. Spectrochimica Acta A., 27(9):1849-1863.

http://dx.doi.org/10.1016/0584-8539(71)80238-6

Bernabei T., Forti P. \& Villasuso R., 2007 - Sails: a new gypsum speleothem from Naica, Chihuahua, Mexico. International Journal of Speleology, 26(1): 23-30.

Beverly M. \& Forti P., 2010 - L'esplorazione della Grotta Palacios nella miniera di Naica. Speleologia, 63 46-49.

Calaforra J.M., Forti P. \& Fernández-Cortés A., 2008 - Speleothems in gypsum caves and their paleoclimatological significance. Environmental Geology, 53: 1099-1105 http://dx.doi.org/10.1007/s00254-007-0737-3

Calvert S.E. \& Pedersen T.F., 1996 - Sedimentary geochemistry of manganese; implications for the environment of formation of manganiferous black shales. Economic Geology, 91(1): 36-47. http://dx.doi.org/10.2113/gsecongeo.91.1.36

Cruz F.W., Karmann I., Viana O., Burns S.J., Ferrari J.A., Vuille M., Sial A.N. \& Moreira M.Z., 2005 Stable isotope study of cave percolation waters in subtropical Brazil: Implications for paleoclimate inferences from speleothems. Chemical Geology, 220: 245-262.

http://dx.doi.org/10.1016/j.chemgeo.2005.04.001
Dunn D. S., Bogart M. B., Brossiaand C. S. \& Cragnolino G. A., 2000 - Corrosion of iron under alternate wet and dry conditions. Corrosion, 56: 470-488. http:/ / dx.doi.org/10.5006/1.3280551

Erwood R.J., Kesler S.E. \& Cloke P.L., 1979 - Compositionally distinct, saline hydrothermal solutions, Naica Mine, Chihuahua, Mexico. Economic Geology, 74: 95-108. http://dx.doi.org/10.2113/gsecongeo.74.1.95

Finch A., Paul A.S., Graham P.W. \& Holmgren K., 2001 - Trace element variation in speleothem aragonite: potential for palaeoenvironmental reconstruction. Earth and Planetary Science Letters, 186: 255-267.

http://dx.doi.org/10.1016/S0012-821X(01)00253-9

Forti P., 1996 - Speleothems and cave minerals in gypsum caves. International Journal of Speleology, 25(3-4): 91-104.

Forti P., 2003 - Un caso evidente di controllo climatico sugli speleotemi: Il moonmilk del Salone Giordani e $i$ "cave raft" del Salone del Fango nella grotta della Spipola (Gessi Bolognesi). Atti $19^{\circ}$ Congresso Nazionale di Speleologia, Trieste. 115-126.

Forti P., 2010 - Genesis and evolution of the caves in the Naica mine (Chihuahua, México). Zeitschrift für Geomorphologie, 54(2): 115-135. http://dx.doi.org/10.1127/0372-8854/2010/0054S2-0007

Forti P. \& Lo Mastro F., 2008 - Il laboratorio sperimentale di -590 nella Miniera di Naica (Messico). Mondo Sotterraneo, 21(1-2): 11-26.

Forti P., Galli E. \& Rossi A., 2008 - Il sistema GessoAnidrite-Calcite: nuovi dati dalle concrezioni della miniera di Naica (Messico) Congresso Nazionale di Speleologia, Iglesias, Aprile 2007, Memorie dell'Istituto Italiano di Speleologia 2(21): 139-149.

Foshag W., 1927 - The selenite caves of Naica, Mexico. American Mineralogist, 12: 252-256.

Franco-Rubio M., 1978 - Estratigrafia del AlbianoCenomaniano en la región de Naica Chihuahua. Revista del Instituto Geológico (México), 2: 132149.

Frech R., Wang E.C. \& Bates J.B., 1980 - The IR and Raman-spectra of $\mathrm{CaCO}_{3}$ (aragonite). Spectrochimica Acta A., 36: 915-919. http://dx.doi.org/10.1016/0584-8539(80)80044-4

García-Guinea J., Morales S., Delgado A., Recio C. \& Calaforra J.M. 2002 - Formation of gigantic gypsum crystals. Journal of the Geological Society of London, 159: 347-350. http://dx.doi. org/10.1144/0016-764902-001

García-Ruiz J.M., Villasuso R., Ayora C., Canals A. \& Otálora F., 2007 - Formation of Natural Gypsum Megacrystals in Naica, Mexico. Geology, 35(4): 327-330. http://dx.doi.org/10.1130/G23393A.1

Garofalo P.S., Fricker M., Günther D., Mercuri A.M., Loreti M., Forti P. \& Capaccioni B., 2010 - A climatic control on the formation of gigantic gypsum crystals within the hypogenic caves of Naica (Mexico)? Earth and Planetary Science Letters, 289: 560-569. http://dx.doi.org/10.1016/j.eps1.2009.11.057 
Gázquez F., Calaforra J.M. \& Forti P., 2011 - Black Mn-Fe Crusts as Markers of Abrupt Palaeoenvironmental Changes in El Soplao Cave (Cantabria, Spain). International Journal of Speleology, 40(2): 163-169.

http://dx.doi.org/10.5038/1827-806X.40.2.8

Gázquez, F., Calaforra, J.M., Rull, F., Forti, P. \& García-Casco, A., 2012 - Distribution survey of Cyanobacteria in three Greek caves of Peloponnese. International Journal of Speleology, 41(1): 113-122. http://dx.doi.org/10.5038/1827-806X.41.1.12

Gunasekaran S., Anbalagan G. \& Pandi S., 2006 - Raman and infrared spectra of carbonates of calcite structure. Journal of Raman Spectroscopy, 37: 892-899.

http://dx.doi.org/10.1002/jrs.1518

Hardie L.A., 1967 - The gypsum-anhydrite equilibrium at one atmosphere pressure. American Mineralogist, 52: 171-200.

Hill C.A. \& Forti P., 1997 - Cave minerals of the World. National Speleological Society, Huntsville.

London D., 2003 - New "Cave of the Crystals" at Naica, Chihuahua, Mexico. Earth Scientist Magazine of School of Geology and Geophysics, University of Oklahoma: 24-27.

Maltsev V.A., 1997 - Minerals of Cupp-Coutunn cave. In: Cave Minerals of The World, 2nd edition. Huntsville, AL: National Speleological Society: 323-328.

Marín-Herrera R.M., Vorgel F. \& Echegoyén R. 2006 - Las megaselenitas del distrito minero de Naica, Chihuahua, una ocurrencia mineralógica anómala. Boletín de Mineralogía, 17: 139 -148.

Martínez-Arkarazo I., Angulo M., Zuloaga O., Usobiaga A. \& Madariaga J.M., 2007 - Spectroscopic characterisation of moonmilk deposits in Pozalagua tourist Cave (Karrantza, Basque Country, North of Spain). Spectrochimica Acta A., 68(4): 1058-1064. http://dx.doi.org/10.1016/j.saa.2007.05.026

Megaw P.K.M., Ruiz J. \& Titley S.R., 1988 - High-temperature, carbonate-hosted $\mathrm{Pb}-\mathrm{Zn}-\mathrm{Ag}(\mathrm{Cu})$ deposits of northern Mexico. Economic Geology, 83: 18561885.

http://dx.doi.org/10.2113/gsecongeo.83.8.1856

Mironova-Ulmanea N., Kuzmina A. \& Grube M., 2009

- Raman and infrared spectromicroscopy of manganese oxides. Journal of Alloys and Compounds, 480: 97-99.

http://dx.doi.org/10.1016/j.jallcom.2008.10.056

Onac B.P., 1996 - Mineralogy of speleothems from caves in the Padurea Craiului Mountains (Romania) and their palaeoclimatic significance. Cave and Karst Science, 23(3): 109-124.

Onac B.P., Pedersen, R.B. \& Tysseland M., 1997 - Presence of rare-earth elements in black ferromanganese coating from Vântului cave (Romania). Journal of Cave and Karst Studies, 59(3): 128131.
Onac B.P. \& Forti P., 2011a - State of the art and challenges in cave minerals studies. Studia UBB Geologia, 56 (1): 33-42. http:/ / dx.doi.org/10.5038/1937-8602.56.1.4

Onac B.P. \& Forti P., 2011b - Minerogenetic mechanisms occurring in the cave environment: an overview. International Journal of Speleology, 40 (2): 79-98.

http://dx.doi.org/10.5038/1827-806X.40.2.1

Ortega R., Maire R., Devès G. \& Quinif Y., 2005 High-resolution mapping of uranium and other trace elements in recrystallized aragonite-calcite speleothems from caves in the Pyrenees (France): Implication for $U$-series dating. Earth and Planetary Science Letters, 237(3-4): 911-923. http://dx.doi.org/10.1016/j.eps1.2005.06.045

Peck S.B., 1986 - Bacterial deposition of iron and manganese oxides in North American caves. National Speleological Society Bulletin, 48(1): 26-30.

Railsback L.B., Brook G.A., Chen J., Kalin R. \& Fleisher C.J. 1994 - Environmental controls on the petrology of a late Holocene speleothem from Botswana with annual layers of aragonite and calcite. Journal of Sedimentary Research, 64: 147-155.

Reich S. \& Thomsen C., 2004 - Raman spectroscopy of graphite. Philosophical Transactions of the Royal Society of London A, 362: 2271-2288.

http://dx.doi.org/10.1098/rsta.2004.1454

Rickwood P.C., 1981 - The largest crystals. American Mineralogist, 66: 885-908.

Ruff Mineralogical database. Accessed 1 March 2012 http://rruff.info

Rutt H.N. \& Nicola J.H., 1974. Raman spectra of carbonates of calcite structure. Journal of Physics C Solid State, 7: 4522.

http://dx.doi.org/10.1088/0022-3719/7/24/015

Sanna L., Saez F., Simonsen S., Constantin S., Calaforra J.M., Forti P. \& Lauritzen S.E. 2010 -Uranium-series dating of gypsum speleothems: methodology and examples. International Journal of Speleology, 39(1): 35-46.

Sanna L., Forti P. \& Lauritzen S.E., 2011 - Preliminary $U / T h$ dating and the evolution of gypsum crystals in Naica caves (Mexico). Acta Carsologica, 40(1): 17-28.

Takahashi H., Maehara I. \& Kaneko N., 1983 - Infrared reflection spectra of gypsum. Spectrochimica Acta A. 39A(5): 449-455. http://dx.doi.org/10.1016/0584-8539(83)80160-3

White W.B., 2006 - Identification of cave minerals by Raman spectroscopy: new technology for non-destructive analysis. International Journal of Speleology, 35(2): 103-107.

White W.B., Vito C. \& Scheetz B.E., 2009 - The mineralogy and trace element chemistry of black manganese oxide deposits from caves. Journal of Cave and Karst Studies, 71(2): 136-143. 